\title{
PENINGKATAN PEMAHAMAN AKUNTANSI DAN \\ PARTISIPASI SISWA MELALUI MODEL PEMBELAJARAN PROBLEM POSING \\ TIPE PRE SOLUTION POSING
}

\author{
Shinta Agustina Siregar \\ Prodi Pendidikan Akuntansi Universitas Negeri Yogyakarta \\ cyentacweetzz@ymail.com \\ Sukanti \\ Jurusan Pendidikan Akuntansi Universitas Negeri Yogyakarta
}

\begin{abstract}
Abstrak
Penelitian ini merupakan Penelitian Tindakan Kelas yang bertujuan meningkatkan Pemahaman Akuntansi dan Partisipasi Siswa Kelas XI Akuntansi 4 SMKN 2 Purworejo Tahun Ajaran 2013/2014 melalui Model Pembelajaran Problem Posing tipe Pre Solution Posing. Pengumpulan data dalam penelitian ini dilakukan dengan menggunakan observasi partisipan, angket, dan tes yang dianalisis menggunakan deskriptif kuantitatif dengan persentase dan kualitatif. Berdasarkan hasil penelitian disimpulkan bahwa terdapat peningkatan persentase skor Partisipasi siswa yang didapat melalui observasi sebesar 79,09\% pada siklus I kemudian meningkat menjadi $92,92 \%$ pada siklus II atau terjadi peningkatan sebesar $13,83 \%$. Berdasarkan angket yang didistribusikan juga terjadi peningkatan skor Partisipasi Siswa sebesar 4,74\% dimana skor pada siklus I sebesar 76,74\% meningkat menjadi 81,48\% pada siklus II. Terdapat peningkatan Pemahaman Akuntansi dari siklus I ke siklus II yang dilihat dari peningkatan post test sebesar 11,25 serta naiknya persentase siswa yang mencapai KKM dari 83,87\% pada siklus I meningkat pada siklus II menjadi $100 \%$.
\end{abstract}

Kata kunci: Problem Posing tipe Pre Solution Posing, Pemahaman Akuntansi, Partisipasi Siswa

\begin{abstract}
The research is a Classroom Action Research that aimed to increase the understanding and participation of grade XI Accounting 4 SMKN 2 Purworejo students academic year of 2013/2014 through the Implementation of Learning Model Problem Posing type Pre solution Posing. The data collection in this research was performed by using participant observation, questionnaires, and tests which were analyzed using the descriptive quantitative with percentage and qualitative. Based on the research findings, it can be concluded that there is a significant increase in the score of student participation which were gained through observation, i.e. 79,09\% in the first cycle. This score then increased 13,83\% to 92,92\% in the second cycle. Based on the research result, there is a significant increase, i.e. $4,74 \%$ on student participation score from the first cycle to the second cycle (i.e. from $76,74 \%$ to $81,48 \%)$. There is a understanding of accounting score increase from the first to second cycle which can be seen from the increase in the post-test score $(11,25)$ as well as the increase in achieving the minimum passing criteria (KKM), from 83,87\% in the first cycle to $100 \%$ in the second cycle.
\end{abstract}


Keywords: Problem Posing tipe Pre Solution Posing, Understanding of Accounting, Student Participation

\section{PENDAHULUAN}

Salah satu regulasi peningkatan mutu pendidikan di Indonesia adalah diberlakukannya Kurikulum Tingkat Satuan Pendidikan (KTSP). Implementasi KTSP di sekolah menuntut para guru dan siswa untuk lebih kreatif dan memiliki inovasi dalam pelaksanaan pembelajaran di kelas. KTSP lebih menekankan pada pencapaian kompetensi siswa, ini berarti dalam pembelajaran akuntansi berpusat kepada siswa (student oriented) dan bukan lagi bersumber pada guru (teacher oriented).

Dalam Pasal 20 UU Tahun 2003, mutu pendidikan erat hubungannya dengan mutu siswa, karena siswa merupakan titik pusat belajar mengajar. Oleh karena itu, dalam meningkatkan mutu pendidikan harus diikuti dengan peningkatan mutu siswa. Peningkatan mutu siswa dapat dilihat pada tingginya tingkat prestasi belajar siswa, sedangkan tingginya tingkat prestasi belajar siswa dipengaruhi oleh pemahaman siswa terhadap materi dan besarnya minat belajar siswa itu sendiri.

Model pembelajaran konvensional seperti menjelaskan materi secara abstrak, hafalan materi dan ceramah dengan komunikasi satu arah yang aktif masih didominasi oleh pengajar, sedangkan siswa biasanya hanya memfokuskan penglihatan dan pendengaran. Kondisi pembelajaran seperti inilah yang mengakibatkan siswa kurang aktif dan pembelajaran yang dilakukan kurang efektif. Penggunaan metode yang kurang sesuai dengan tujuan pengajaran akan menjadi kendala dalam mencapai tujuan yang telah dirumuskan.

Siswa terkadang sulit mengartikan atau mengerti penjelasan dari gurunya ini terlihat dari hasil observasi peneliti mengamati langsung didalam kelas dan mewawancarai guru akuntansi di kelas XI akuntansi 4 SMK Negeri 2 Purworejo tahun ajaran 2013/2014, terdapat siswa yang memiliki partisipasi belajar di kelas masih rendah. Terlihat di kelas masih ada siswa ketika dijelaskan oleh gurunya sekitar 46,87\% atau sebanyak 15 siswa mengobrol dengan teman sebangkunya dan sekitar 38,71\% atau 12 orang siswa masih terlihat mengerjakan pekerjaan rumah $(\mathrm{PR})$ di dalam kelas. Kemudian setelah guru selesai memberikan penjelasan, guru memberikan pertanyaan kepada siswa sekitar $87,10 \%$ siswa hanya diam tidak ada respon ketika guru memberikan pertanyaan dan hanya ada $12,90 \%$ siswa yang aktif bertanya dan memberikan respon 
menjawab pertanyaan dengan baik ketika guru bertanya ini membuktikan bahwa tingkat partisipasi siswa masih rendah padahal guru telah memberikan pengajaran semaksimal mungkin kepada siswanya.

Tingkat pemahaman dari siswa juga kurang, ini terlihat dari cara siswa menjawab pertanyaan yang diberikan oleh guru hanya $40 \%$ benar dan terlihat juga masih ada 8 siswa atau $25,81 \%$ yang belum mencapai kriteria ketuntasan minimum (KKM) saat ulangan harian ke-1 dalam kompetensi dasar membukukan data piutang ke masing-masing kartu piutang.

Begitu juga yang terjadi dalam pembelajaran akuntansi di SMK Negeri 2 Purworejo khususnya di kelas XI Akuntansi 4. Pembelajaran masih menggunakan model pembelajaran konvensional dimana guru berperan aktif dalam memberikan materi dan siswa dengan pasif menerima materi yang disampaikan oleh gurunya. Partisipasi siswa juga masih rendah ditandai dengan saat guru sedang memberikan penjelasan siswa sebagian besar kurang memperhatikan ada yang mengobrol dengan teman sebangkunya, ada yang sibuk menggambar, ada yang hanya duduk diam tidak melakukan aktivitas apapun yang merespon gurunya seperti mencatat, menandai, memberikan pertanyaan dan menjawab pertanyaan terkait dengan materi yang telah disampaikan oleh guru didalam kelas. "Mengajar dalam konteks standar proses pendidikan tidak hanya sekedar menyampaikan materi pelajaran, akan tetapi juga dimaknai sebagai proses mengatur lingkungan supaya siswa belajar" (Wina Sanjaya, 2012: 103).

Sejalan dengan pendapat tersebut yang dikemukakan oleh Dick dan Carey dalam Hamzah B. Uno, (2008: 6):

Berdasarkan prinsip student centered peserta didik merupakan pusat dari suatu kegiatan belajar. Hal ini dikenal dengan istilah cara belajar aktif, terjemahan dari student active training, yang bermakna adalah proses pembelajaran akan lebih berhasil apabila peserta didik secara aktif melakukan latihan langsung dan relevan dengan tujuan pembelajaran yang telah ditetapkan (Dick dan Carey, dalam Hamzah B.Uno, 2008: 6).

Dengan adanya partisipasi maka pemahaman siswa juga akan beriringan meningkat karena apabila partisipasi siswa meningkat maka tingkat pemahaman juga akan cepat meningkat. "Pemahaman mencakup kemampuan untuk menangkap makna dan arti dari bahan yang dipelajari” (W.S. Winkel, 2004: 274). 
Kemudian pendapat lain mengenai Pemahaman menurut Anas Sujiono (2011: 50) bahwa:

Pemahaman (comprehension) adalah kemampuan seseorang untuk mengerti atau memahami sesuatu setelah sesuatu itu diketahui dan diingat. Dengan kata lain, memahami adalah mengetahui tentang sesuatu dan dapat melihatnya dari berbagai segi. Seorang peserta didik dikatakan memahami sesuatu apabila ia dapat memberikan penjelasan atau memberikan uraian yang lebih rinci tentang hal itu dengan menggunakan kata-kata sendiri (Anas Sujiono, 2011: 50).

Dengan adanya masalah tersebut, maka perlu diterapkan model pembelajaran yang melibatkan siswa secara aktif dan menyenangkan serta melibatkan siswa dalam kegiatan diskusi di kelas. Salah satu model pembelajaran yang dapat digunakan yaitu model pembelajaran Problem Posing Tipe Pre Solution Posing.

Model pembelajaran problem posing adalah suatu model pembelajaran yang mewajibkan siswa untuk mengajukan soal sendiri melalui belajar soal (berlatih soal) secara mandiri. Sedangkan pre solution posing yaitu siswa membuat soal sesuai situasi yang diberikan guru kemudian menyelesaikannya sendiri.
Model pembelajaran ini dapat memberikan kesempatan kepada siswa untuk membuat soal sesuai situasi yang diberikan oleh guru dan menyelesaikannya sendiri atau diselesaikan oleh siswa yang lain, sehingga akan terlihat kegiatan siswa. Siswa akan lebih dominan dibandingkan dengan guru. Soal yang telah disusun dapat diajukan sebagai bahan diskusi bersama teman sekelompok apabila muncul permasalahan dapat didiskusikan dengan guru. Dengan demikian, dapat dilihat sejauh mana siswa dalam memahami materi yang telah diberikan.

Kompetensi dasar yang dipilih dalam penelitian ini yaitu menyusun laporan rekapitulasi piutang. Berdasarkan hasil observasi dan wawancara dengan guru akuntansi, dipilihnya kompetensi dasar ini karena pada kompetensi dasar sebelumnya yaitu membukukan data piutang ke masing-masing kartu piutang terjadi masalah yaitu masih ada siswa yang belum mencapai kriteria ketuntasan minimum yaitu sebanyak 8 orang atau sekitar $25,81 \%$ dan kompetensi ini juga masih dalam standar kompetensi yang sama. Selain itu berdasarkan hasil wawancara dengan guru akuntansi juga mengatakan bahwa kompetensi ini bisa digunakan karena kompetensi dasar menyusun laporan rekapitulasi piutang merupakan proses penyusunan akhir 
setelah kompetensi dasar lainnya sehingga harapan dari seorang guru adalah siswa mampu menyusun laporan rekapitulasi piutang.

Berdasarkan latar belakang di atas, maka penulis tertarik untuk mengadakan penelitian dengan judul "Peningkatan Pemahaman dan Partisipasi Siswa Pada Kompetensi Dasar Menyusun Laporan Rekapitulasi Piutang Melalui Model Pembelajaran Problem Posing Tipe Pre Solution Posing Pada Siswa Kelas XI Akuntansi 4 di SMK Negeri 2 Purworejo Tahun Ajaran 2013/2014”.

\section{METODE}

\section{Desain Penelitian}

Penelitian ini merupakan penelitian tindakan kelas (Classroom Action Research) yang bersifat kolaboratif dan partisipatif, artinya peneliti tidak melakukan penelitian sendiri, namun berkolaborasi atau bekerjasama dengan guru mata pelajaran Akuntansi SMK Negeri 2 Purworejo. Secara Partisipatif bersama-sama dengan mitra peneliti akan melaksanakan penelitian ini langkah demi langkah. "Penelitian tindakan kelas (PTK) adalah penelitian yang dilakukan oleh guru di kelasnya sendiri melalui refleksi diri dengan tujuan untuk memperbaiki kinerjanya sehingga hasil belajar siswa meningkat" (Zainal Aqib et al. 2008: 3).
Penelitian ini menggunakan model penelitian tindakan dari Kemmis dan Teggart, yaitu bentuk spiral dari siklus yang satu ke siklus berikutnya. Setiap siklus meliputi planning (rencana), action (tindakan), observation (pengamatan), dan reflection (refleksi). Peneliti melaksanakan penelitian sebanyak 2 siklus yang terdiri dari 8 tahapan yaitu perencanaan pertama, tindakan pertama, pengamatan pertama, refleksi pertama, revisi terhadap perencanaan pertama, tindakan kedua, pengamatan kedua, dan, refleksi kedua. Menurut Suharsimi (2012: 16) secara garis besar terdiri dari empat tahapan. Desain Penelitian Tindakan dapat digambarkan sebagai berikut:

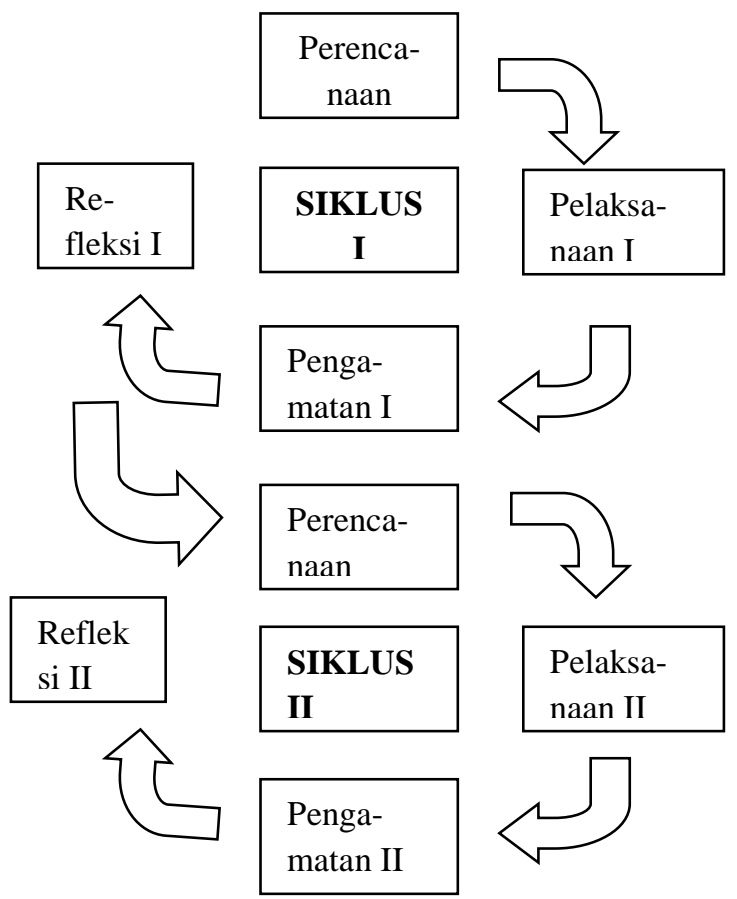

Gambar 1. Penelitian Tindakan Model Kemmis dan Taggart dalam Suharsimi Arikunto (2012: 16) 


\section{Subjek Penelitian}

Subjek penelitian ini yaitu pada siswa kelas XI Akuntansi 4 SMK Negeri 2 Purworejo yang berjumlah 31 siswa.

\section{Data, Instrumen, dan Teknik Pengumpulan}

Jenis data yang diperoleh dari observasi, angket, dan tes merupakan data kuantitatif. Teknik pengumpulan data dalam penelitian ini dilakukan dengan menggunakan observasi partisipan, angket, dan tes. Instrumen penelitian yang digunakan adalah lembar observasi, angket, dan tes. Observasi dan angket digunakan untuk memperoleh data peningkatan Partisipasi siswa. Angket didistribusikan kepada siswa setiap siklus pada akhir pembelajaran. Adapun tes digunakan untuk memperoleh data peningkatan Pemahaman Akuntansi. Pre test dilakukan setiap akan memulai penyajian materi baru pada tiap siklus. Tujuannya adalah untuk mengidentifikasi taraf pengetahuan siswa mengenai bahan yang akan disajikan. Sedangkan post test adalah kegiatan evaluasi yang dilakukan guru setiap akhir penyajian materi pada tiap siklus. Tujuannya adalah untuk mengetahui taraf penguasaan siswa atas materi yang telah diajarkan.

\section{Teknik Analisis Data}

Teknik analisis data yang digunakan dalam penelitian ini adalah analisis data deskriptif kuantitatif dengan persentase dan kualitatif. Dalam penelitian ini, data yang diperoleh dari hasil observasi, angket, dan tes adalah data kuantitatif, yang menunjukkan penilaian atas kemunculan kegiatan yang mencerminkan Pemahaman Akuntansi dan Partisipasi siswa dengan kriteria yang telah ditentukan. Data yang diperoleh selanjutnya akan dianalisis untuk mengetahui persentase skor Partisipasi siswa sebagai berikut (Sugiyono, 2012: 144):

1. Menentukan kriteria pemberian skor terhadap masing-masing indikator ada setiap aspek yang diamati.

2. Menjumlahkan skor untuk masingmasing aspek yang diamati.

3. Menghitung skor pada setiap aspek yang diamati dengan rumus (dalam hal ini skor aspek yang dihitung adalah partisipasi siswa) :

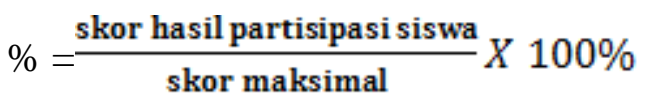

Sedangkan teknik analisis kuantitatif untuk menghitung peningkatan pemahaman akuntansi didalam kelas 
adalah menggunakan rumus sebagai berikut:

Rumus Mean

$$
M e=\frac{\sum x i}{N}
$$

Keterangan :

$$
\begin{aligned}
M e & : \text { Rata-rata (mean) } \\
\sum x i & : \text { Jumlah semua nilai } \\
N & : \text { Jumlah individu }
\end{aligned}
$$

\section{Indikator Keberhasilan}

Suatu tindakan dikatakan berhasil apabila setelah dilakukan penerapan model pembelajaran Problem posing tipe pre solution posing mampu meningkatkan partisipasi dan pemahaman belajar siswa sehingga mencapai kriteria yang telah ditentukan. Dalam penelitian ini indikator yang dicapai dapat dilihat dari aspek-aspek yang telah tertera dalam partisipasi siswa. Indikator-indikator dari partisipasi siswa dalam belajar tersebut meliputi: terampil menyelesaikan soal-soal akuntansi yang diberikan, menunjukkan antusiasme terhadap kegiatan pembelajaran, menunjukkan proses yang efisien dalam menyelesaikan masalah/soal akuntansi, ingin memecahkan masalah/soal yang dianggap paling sulit, merespon dengan baik setiap pertanyaan yang diberikan oleh guru, dapat mempertahankan pendapat yang diajukan, menunjukkan antusiasme dalam kelompok untuk menyelesaikan masalah/soal yang diajukan kelompok lain dan senang menyelesaikan soal-soal penguatan dari guru secara individual. Indikator tersebut terlaksana jika terjadi peningkatan pada aspek partisipasi yaitu:

"Dilihat dari segi proses, pembelajaran dikatakan berhasil dan berkualitas jika seluruhnya atau setidaktidaknya sebagian besar $(75 \%)$ peserta didik terlibat secara aktif, baik fisik, mental, maupun sosial dalam proses pembelajaran" (Mulyasa, 2008: 101). Untuk mengetahui skor hasil dari tindakan yang dilakukan, skor tersebut dijumlahkan dan dipersentasekan dengan cara skor total dibagi dengan skor maksimum kemudian dikalikan $100 \%$. Skor inilah yang akan mencerminkan kondisi Partisipasi siswa dalam belajar akuntansi setelah adanya tindakan yang telah dilakukan. Tindakan ini dinyatakan berhasil apabila adanya peningkatan partisipasi siswa dalam belajar akuntansi dari siklus I ke siklus II.

Indikator keberhasilan Pemahaman akuntansi adalah adanya peningkatan hasil belajar siswa dalam pembelajaran akuntansi yang dapat dililhat dari peningkatan nilai tes pada siklus I dan siklus II. Untuk melihat keberhasilan tindakan dapat dilihat adanya peningkatan 
nilai, baik secara individu maupun nilai rata-rata kelas dari siklus sebelumnya. Apabila hasil tindakan tersebut mengalami kenaikan dari siklus I hingga siklus II maka tindakan dinyatakan berhasil.

\section{HASIL DAN PEMBAHASAN}

\section{Partisipasi Siswa}

\section{a. Indikator terampil menyelesaikan} soal-soal akuntansi yang diberikan

Skor pada siklus I menunjukkan bahwa indikator Terampil menyelesaikan soal-soal akuntansi yang diberikan hanya sebesar 74,72\%, dan skor dari angket Partisipasi siswa pada indikator tersebut hanya sebesar 74,66\% ini menunjukkan bahwa indikator Terampil menyelesaikan soal-soal akuntansi yang diberikan masih tergolong rendah. Sedangkan pada siklus II indikator Terampil menyelesaikan soalsoal akuntansi yang diberikan meningkat menjadi 90,85\%, hal ini menunjukkan adanya peningkatan sebesar 16,13\%. Selain itu, data dari angket menunjukkan bahwa pada siklus II mengalami peningkatan sebesar 4,97\% menjadi $79,63 \%$. Berdasarkan pengamatan yang dilakukan selama proses pembelajaran dari siklus I ke siklus II, dapat dilihat bahwa pada siklus I sebagian besar siswa tidak bertanya kepada guru ketika mengalami kesulitan. Siswa lebih memilih untuk bertanya kepada teman daripada guru. Hal ini disebabkan karena siswa merasa lebih mudah memahami materi dengan bahasa yang digunakan temannya saat menjelaskan. Walau demikian, baik data observasi maupun angket indikator Terampil menyelesaikan soal-soal akuntansi yang diberikan mengalami peningkatan dan telah mencapai kriteria minimal $75 \%$.

Dalam model pembelajaran problem posing tipe pre solution posing kelas menjadi lebih terkondisi bagi siswa untuk mau mengerjakan soal yang diberikan guru secara tuntas dengan sungguh-sungguh. Pada siklus I, terdapat 1 orang siswa yang hanya mengerjakan kurang dari $50 \%$ dan 3 orang siswa yang mengerjakan lebih dari 50\% tugas yang diberikan. Namun pada siklus II, semua siswa telah mengerjakan sampai selesai tugas yang diberikan, hanya 2 orang siswa yang belum selesai hanya mengerjakan lebih dari $50 \%$ dari tugas yang diberikan. Hal ini sejalan dengan pendapat Wina Sanjaya (2012: 249) bahwa pembelajaran ini dapat menambah kemampuan berpikir siswa, menemukan informasi dari berbagai sumber, dan belajar dari siswa yang lain sehingga siswa menjadi lebih tekun dalam mengerjakan tugas yang diberikan guru.

\section{b. Indikator Menunjukkan antusiasme terhadap kegiatan pembelajaran}


Terjadi peningkatan pada siklus I ke siklus II sebesar $11,83 \%$ Peningkatan skor Partisipasi siswa dalam belajar akuntansi juga ditunjukkan dari data angket dimana terjadi peningkatan sebesar $3,32 \%$. Walau demikian, baik data observasi maupun angket indikator Menunjukkan antusiasme terhadap kegiatan pembelajaran sama-sama mengalami peningkatan dan telah dicapai. Dalam model pembelajaran problem posing tipe pre solution posing, siswa terlihat aktif ini terlihat pada saat berdiskusi untuk membuat soal siswa ikut serta berfikir dan menuangkan dalam tulisan kemudian saat menjawab soal dari kelompok lain siswa secara antuasias mengerjakan soal tersebut dan ketika ada kelompok presenter siswa dari kelompok lain ikut menanggapi diskusi tersebut. Adanya diskusi kelompok di dalamnya mampu menciptakan pembelajaran yang menarik, bermakna dan dengan berlatih soal memberi tantangan bagi siswa untuk memahami materi sehingga siswa memiliki antusiasme dalam kegiatan pembelajaran.

\section{c. Indikator Menunjukkan proses yang efisien dalam menyelesaikan soal akuntansi.}

Terjadi peningkatan skor pada indikator ini sebesar $14,95 \%$ dari data siklus I yaitu sebesar $74,16 \%$ ke siklus II menjadi sebesar $89,11 \%$. Selaras dengan data tersebut, pada angket terjadi peningkatan skor sebesar 9,34\%. Dengan diterapkannya Model Pembelajaran Problem Posing Tipe Pre Solution Posing mampu memberikan dampak positif terhadap siswa dalam menyelesaikan soal akuntansi sehingga siswa dapat memanfaatkan waktu secara efisien dalam mengerjakannya. Terbangunnya partisipasi siswa membuat siswa lebih semangat dalam mengerjakan soal/masalah akuntansi.

\section{d. Indikator Ingin memecahkan} masalah yang dianggap paling sulit.

Pada indikator ini terdapat peningkatan sebesar $17,18 \%$ dari data siklus I yaitu sebesar 79,99\% ke siklus II menjadi sebesar $97,17 \%$. Sedangkan data angket menunjukkan peningkatan sebesar $5,90 \%$ dari data siklus I yaitu sebesar $75,28 \%$ ke siklus II menjadi sebesar $81,18 \%$ walaupun peningkatan data angket ini tidak sebesar skor pengamatan namun kegiatan pembelajaran sama-sama mengalami peningkatan. Terbangunnya partisipasi siswa dalam belajar akan membuat siswa semakin tertantang untuk mengerjakan soal-soal yang memiliki tingkat kesukaran yang lebih tinggi karena 
siswa akan merasa jenuh jika soal yang dikerjakan selalu sama.

\section{e. Indikator merespon dengan baik pertanyaan dari guru}

Peningkatan sebesar 5,43\% terjadi dari siklus I ke siklus II. Berdasarkan data angket yang diperoleh, terjadi kenaikan skor sebesar 5,63\%. Dari data yang diperoleh selama proses pembelajaran, siswa terlihat lebih bersemangat dalam mengikuti dengan model pembelajaran yang baru. Hal ini menyebabkan semakin memudahkan siswa dalam memahami materi dan ketika guru bertanya siswa secara bersemangat menjawab pertanyaan dari guru menunjukkan partisipasi siswa semakin meningkat dengan digunakannya model pembelajaran problem posing tipe pre solution posing. Jika dilihat dari angket, menunjukkan hasil angket yang lebih besar lebih dari pengamatan ini membuktikan siswa dapat merespon dengan baik pertanyaan dari guru ketika digunakannya model pembelajaran tersebut (Wina Sanjaya, 2012: 247). Interaksi tatap muka siswa dengan siswa lain menjadi lebih efektif begitu pula interaksi siswa dengan guru menjadi lebih komunikatif. Kondisi ini memberikan dampak bahwa siswa dapat merespon dengan baik pertanyaan dari guru.

\section{f. Indikator dapat mempertahankan pendapat yang diajukan}

Terjadi peningkatan skor dari siklus I sebesar $14,80 \%$ ke siklus II. Dilihat dari data angket juga terjadi peningkatan skor sebesar 2,85\%. Berdasarkan data yang diperoleh selama proses pembelajaran dapat terlihat bahwa pada dasarnya siswa mengetahui dan mampu menjelaskan alasan dari pekerjaan mereka. Selain itu jika terjadi perbedaan dalam mengerjakan soal, siswa akan berdiskusi dan berpendapat untuk membuktikan pendapat siapa yang benar. Model pembelajaran problem posing tipe pre solution posing yang dilaksanakan selama di kelas membuat siswa memiliki pemahaman yang lebih karena selain dengan penjelasan lisan, siswa juga melakukan diskusi, tidak hanya sampai diskusi selanjutnya siswa juga melakukan konfirmasi terhadap hasil diskusi pada akhir pembelajaran, sehingga siswa dapat menjawab pertanyaan yang ada dan memiliki alasan yang tepat atas jawaban tersebut.

\section{g. Indikator Menunjukkan antusiasme dalam kelompok untuk menyelesaikan masalah/soal yang diajukan kelompok lain.}

Diperoleh peningkatan skor sebesar $0,13 \%$ dari siklus I ke siklus II. 
Peningkatan dari data angket ditunjukkan sebesar 5,05\%. Dengan adanya model pembelajaran problem posing tipe pre solution posing yaitu model pembelajaran yang mewajibkan siswa aktif dengan cara berlatih soal dan adanya diskusi kelompok untuk masing-masing siswa membuat soal akuntansi sesuai dengan permasalahan siswa lebih bersemangat dalam membuat soal karena soal yang ditujukan selain untuk meningkatkan pemahaman siswa juga untuk dikerjakan kelompok lain. Ketika siswa mengerjakan soal dari kelompok lain siswa lebih bersemangat mengerjakannya daripada mengerjakan soal yang selalu ada didalam referensi. Hal ini membuktikan adanya peningkatan partisipasi siswa karena secara antusias mengerjakan soal yang diajukan oleh siswa lain.

\section{h. Indikator senang menyelesaikan} soal-soal penguatan dari guru secara individual.

Terjadi peningkatan skor sebesar 20,05\% dari siklus I ke siklus II. Selaras dengan data angket juga menunjukkan adanya peningkatan skor sebesar 3,36\%. Dengan dilakukannya model pembelajaran problem posing tipe pre solution posing yaitu model pembelajaran yang mewajibkan siswa untuk berlatih soal maka siswa terbiasa berlatih sehingga pada saat diberikan tugas secara individual siswa senang mengerjakannya. Siswa juga menjadi lebih mudah dalam menafsirkan soal karena sudah terbiasa berlatih soal sehingga dalam mengerjakan soal penguatan dari guru, siswa secara efisien menyelesaikannya dan segera mengumpulkan jika telah selesai ini menunjukkan adanya partisipasi siswa dalam mengerjakan soal penguatan dari guru.

\section{Pemahaman Akuntansi}

Selain penarikan kesimpulan atas indikator Partisipasi siswa dalam belajar akuntansi, disajikan pula kesimpulan mengenai peningkatan Pemahaman siswa dalam belajar akuntansi selama proses pembelajaran dengan model pembelajaran problem posing tipe pre solution posing. Dari data yang diperoleh, dapat dilihat bahwa nilai rata-rata pre test dan post test siswa pada siklus I dengan menggunakan model pembelajaran problem posing tipe pre solution posing mengalami peningkatan sebesar 41,33. Pada siklus II, nilai rata-rata pre test dan post test siswa mengalami peningkatan sebesar 32,19. Selain itu, terdapat peningkatan pemahaman siswa dalam belajar akuntansi dari siklus I ke siklus II yang dilihat dari peningkatan post test sebesar 11,25 serta naiknya persentase ketuntasan siswa dari 
$83,87 \%$ pada siklus I meningkat pada siklus II menjadi 100\%. Dari data yang diperoleh juga terlihat secara individu, pemahaman siswa dalam belajar akuntansi juga telah mengalami peningkatan dari siklus I ke siklus II. Jadi dapat disimpulkan bahwa secara individu dan keseluruhan terdapat peningkatan pemahaman siswa dalam belajar akuntansi dengan menggunakan model pembelajaran problem posing tipe pre solution posing.

\section{SIMPULAN DAN SARAN}

\section{Simpulan}

Berdasarkan hasil penelitian dan pembahasan dapat disimpulkan sebagai berikut:

a. Penerapan Model Pembelajaran Problem Posing Tipe Pre Solution Posing dapat meningkatkan Partisipasi Siswa Kompetensi Dasar Menyusun Laporan Rekapitulasi Piutang Siswa Kelas XI Akuntansi 4 SMK Negeri 2 Purworejo Tahun Ajaran 2013/2014. Hal tersebut didukung dengan data penelitian yang menunjukkan adanya peningkatan persentase skor Partisipasi Siswa dalam belajar akuntansi yang didapat melalui observasi dengan pedoman observasi diperoleh skor sebesar 79,09\% pada siklus I kemudian meningkat menjadi $92,92 \%$ pada siklus II atau terjadi peningkatan sebesar
13,83\%. Berdasarkan angket yang didistribusikan kepada siswa juga terjadi peningkatan skor Partisipasi Siswa dalam belajar akuntansi sebesar $4,74 \%$ dimana skor pada siklus I sebesar $76,74 \%$ meningkat menjadi $81,48 \%$ pada siklus II.

b. Penerapan Model Pembelajaran Problem Posing Tipe Pre Solution Posing dapat meningkatkan Pemahaman Siswa pada Kompetensi Dasar Menyusun Laporan Rekapitulasi Piutang Siswa Kelas XI Akuntansi 4 SMK Negeri 1 Purworejo Tahun Ajaran 2013/2014. Dari data yang diperoleh, nilai rata-rata pre test dan post test siswa pada siklus I mengalami peningkatan sebesar 41,33. Pada siklus II, nilai rata-rata pre test dan post test siswa mengalami peningkatan sebesar 32,19. Selain itu, terdapat peningkatan pemahaman siswa dari siklus I ke siklus II yang dilihat dari peningkatan post test sebesar 11,25 serta naiknya persentase ketuntasan siswa dari $83,87 \%$ pada siklus I meningkat pada siklus II menjadi $100 \%$.

\section{Saran}

Berdasarkan hasil penelitian, beberapa saran diberikan kepada guru dan siswa. Dalam pelaksanaan pembelajaran, guru sebaiknya menerapkan model 
pembelajaran yang bervariasi sehingga mampu meningkatkan Pemahaman Akuntansi dan Partisipasi Siswa. Guru dapat menerapkan Model Pembelajaran problem posing tipe pre solution posing pada khususnya agar tercipta suasana belajar yang nyaman dan menyenangkan sehingga Pemahaman Akuntansi dan Partisipasi Siswa lebih optimal. Selain itu, siswa perlu meningkatkan partisipasinya dalam belajar, terutama dalam menyelesaikan soal-soal dan dalam bertanya dan menjawab pertanyaan dari guru.

\section{DAFTAR PUSTAKA}

Anas Sudijono. (2011). Evaluasi Pendidikan. Jakarta: PT RajaGrafindo Persada.

Hamzah B. Uno. (2012). Model Pembelajaran Menciptakan Proses Belajar Mengajar Yang Kreatif dan Efektif. Jakarta: PT Bumi Aksara.

Mulyasa, E. (2008). Kurikulum Tingkat Satuan Pendidikan: Suatu Panduan Praktis. Bandung: PT Remaja Rosdakarya.

Sugiyono. (2012). Metode Penelitian Pendidikan. Bandung: Alfabeta.

(2012). Statistika untuk Penelitian. Bandung: Alfabeta.

Suharsimi Arikunto. (2012). Penelitian Tindakan Kelas. Jakarta: PT Bumi Aksara.
Wina Sanjaya. (2012). Strategi Pembelajaran Berorientasi Standar Proses Pendidikan. Jakarta: Kencana.

W.S Winkel. (2004). Psikologi Pendidikan Dan Evaluasi Belajar. Jakarta : PT. Gramedia.

Zainal Aqib et al. (2008). Penelitian Tindakan Kelas untuk Guru SMP, SMA, SMK. Bandung: CV. YRAMA WIDYA. 